\title{
Predicting Students' Performance in the Senior Secondary Certificate Examinations from Performance in the Junior Secondary Certificate Examinations in Ondo State, Nigeria
}

\author{
Adeyemi, T. O. \\ Department of Educational Foundations and Management, \\ University of Ado-Ekiti, P. M. B 5363, Ado-Ekiti, Nigeria
}

\begin{abstract}
The predictive strength of the Junior Secondary Certificate (JSC) examinations in predicting the performance of students in the Senior Secondary Certificate (SSC) examinations in Ondo State, Nigeria was examined In this article. The study explored a correlation design. The study population comprised all the 257 secondary schools in the State. Out of this population, a sample of 206 schools was selected through the stratified random sampling technique. Data were collected through an inventory and analysed with the use of z- test, correlation analysis and multiple regression. The findings revealed that the JSC examinations were a good predictor of performance at SSC examination. Since the performance level was generally low in both examinations, it was recommended that the State government should intensify more efforts in ensuring better teaching and learning strategies in schools through effective supervision and monitoring of schools.
\end{abstract}

Keyword: Junior, Senior, Secondary, Certificate, Examination, Relationship, Prediction

\section{Introduction}

Examinations in Nigerian schools dated back to the advent of formal education. The 1887 Education Ordinance made provision for public examinations in schools that have attained the requisite percentage of proficiency (Adesina, 1977). Thus the National Policy of Education (1998) stipulated that all secondary schools should gear their programmes to meet the requirements of examinations being conducted for the Senior School Certificate. The pattern of grading candidates' scores in the examinations was such that the distinction grade was represented by $\mathrm{A} 1$ to $\mathrm{B} 3$. The credit grade was represented by $\mathrm{C} 4$ to $\mathrm{C} 6$. The ordinary pass grade was represented by D7 and E8 while the failure grade was represented by F9 (WAEC, 2002). It needs to be mentioned however, that the distinction and credit grades are the only requisite qualifications for admissions into universities in Nigeria and candidates must have at least credit in five subjects including English Language in order to qualify for admission (JAMB, 2002).

Thus, examinations occupy a unique position as a measure of quality within the educational system of Ondo State, Nigeria. They are either internal or public. Internal examinations are the examinations that are set by teachers within a school system. These could be in the form of tests and end of term examinations. Public examinations on the other hand, are examinations that are conducted by recognised examining bodies. As such, the examinations such as the Senior Secondary Certificate (SSC) examinations and the Junior Secondary Certificate (JSC) are regarded as external examinations. This is in the sense that the examining boards conducting these examinations did not themselves organize instructional courses nor prepare students for the examinations. They are examinations that are designed and organised under specific terms and conditions and are based on norms that were regarded as standards (Salami 1992). They are designed to evaluate performance at the end of a course of study or programme. However, despite the unique position of examinations in the educational system, there have been conflicting reports on the predictive strength of the JSC 
examinations at predicting performance in the SSC examinations (Ondo State, Ministry of Education, 2001, Asaolu, 2002).

\section{Literature Review}

The term 'academic performance' has been described as the scholastic standing of a student at a given moment. It refers to how an individual is able to demonstrate his or her intellectual abilities. This scholastic standing could be explained as the grades obtained in a course or groups of courses taken (Daniels and Schouten, 1970, Owoyemi, 2000). Thus, in predicting academic performance, Daniels and Schouten (1970) emphasized the use of grades in examinations and reported that grades could serve as prediction measures and as criterion measures. They argued that a prediction of a future examination result could be made with reasonable success on the basis of the results of a previous examination. Findings made by Al-Shorayye (1995) and Adeyemi (1998) led credence to this point. The findings supported the findings of other researchers that the GCE and Secondary School Certificate examination results provided the best predictor of university performance (Ubokobong, 1993).

Findings made by Peers \& Johnston (1994) confirmed the validity of the number and grades of passes in the Scottish Certificate of Education in predicting first year and final year university performance. Gay (1996) too, argued that high school grades could be used to predict college grades. These findings were contrary to O'Rourke, Martin \& Hurley's (1989) findings that the Scholastic Aptitude Test (SAT) is unable to predict examination performance as effectively as the Leaving Certificate Examination (LCE) point scores.

In Nigeria, researchers have had divergent findings on the predictive validity of some examinations (Alonge, 1998, Adeyemo 2001). In other developing countries, the index of academic performance varied from one country to another. Othuon \& Kishor (1994) too, found that the Kenya Certificate of Primary Education scores had a moderate positive linear relationship with the Certificate of Secondary Education grades. In some other States, performance in JSC examinations has been found to be significantly related to the performance in SSC examinations (Adeyemo, 2001; Adebayo, 2002). However, some researchers have found no significant relationship between the performance in JSC examinations and performance in SSC examinations (Omonijo, 2001). Considering the divergent views and findings of previous researchers on the predictive validity of the JSC examinations, this study intended to examine the JSC examinations in Ondo State, Nigeria to determine whether or not it could effectively predict students' performance in the SSC examinations.

\section{Statement of the Problem.}

The predictive strength of certain examinations has been a matter of concern to many researchers (Al-Shorayye, 1995; Adebayo, 2002). While some researchers were of the opinion that certain examinations such as the Scholastic Aptitude Test (SAT) could predict university grades in some courses (Al-Shorayye, 1995), others argued that certain low-level examinations could not effectively predict performance at higher level examinations (Adebayo, 2002). The problem of this study therefore was to determine how effective the performance of students in the JSC examination in predicting the performance of the same students in the SSC examinations. In addressing this problem, the following research questions were raised.

1. What is the level of performance of students in the junior secondary certificate (JSC) and the senior secondary certificate (SSC) examinations in secondary schools in Ondo State, Nigeria?

2. Is there any relationship between the performance of students in the junior secondary certificate (JSC) and the performance in the senior secondary certificate (SSC) examinations? 
3. Is the junior secondary certificate (JSC) examinations a good predictor of performance in the senior secondary certificate (SSC) examinations?

\section{Method}

\section{Research Design}

This study was designed along the lines of a correlational research. Gay (1996) described correlational research as that involving the collecting of data in order to determine whether, and to what degree, a relationship exists between two or more quantifiable variables.

\section{Population of the Study}

The study population comprised of all the 257 secondary schools that presented candidates for the year 2000 junior secondary certificate (JSC) examinations and the year 2003 senior secondary certificate (SSC) examinations in Ondo State, Nigeria. The population is made up of 110 urban school and 147 schools. It also embraced all the 13 single-sex schools and 244 mixed schools.

\section{Sample and Sampling Technique}

A sample of 218 schools ( $85 \%$ of the population) was drawn from the study population. The method of selection was through the stratified random sampling technique taking into consideration the location of the schools. Thus, the sample was made up of 94 urban (43\%) and $124(57 \%)$ rural secondary schools.

\section{Research Instrument}

The instrument used to collect data for the study was an inventory. The inventory requested among other things, data on enrolment figures and students' grades in three major subjects in schools' curriculum namely English Language, Mathematics and Integrated Science in the 2000 JSC examinations as well as students' grades in English Language, Mathematics, Physics, Chemistry and Biology in the 2003 SSC examinations. The choice of the subjects was in accordance with the National Policy on Education (1998) which regarded these subjects as core subjects in the secondary school curriculum. Bello (2000) too, reported that the Nigerian science curricula are subject-based with Physics, Chemistry and Biology being the important core science subjects. The data collected were analysed with the use of the ztest statistic, correlation analysis and multiple regression.

\section{Data Analysis}

In analyzing the data collected for the study, emphasis was placed on the performance level of students in the $2000 \mathrm{JSC}$ and the 2003 SSC examinations. In computing performance in the examinations, the frequency counts of the number of students who obtained credit grades 1 to 6 in each subject were transformed from discrete data into continuous data through secondary analysis. Table 1 shows the performance level in the JSC Examinations in the State.

Table 1: Credit Performance Level in JSC Examinations in Sampled Schools

\begin{tabular}{cccc}
\hline Years & $\begin{array}{c}\text { English language } \\
\%\end{array}$ & $\begin{array}{c}\text { Mathematics } \\
\%\end{array}$ & $\begin{array}{c}\text { Integrated Science } \\
\%\end{array}$ \\
\hline 2000 & 29.8 & 14.2 & 22.3 \\
2001 & 31.3 & 26.1 & 29.1 \\
2002 & 38.5 & 36.2 & 38.9 \\
2003 & 38.6 & 38.9 & 39.2 \\
\hline Source. Statistics Division, Ministry of Education, Akure
\end{tabular}

As indicated in Table 1, the performance level of students in the three subjects in the JSC examinations in the State was low in each of the three subjects. There was no year where the performance level reached $50 \%$ in any subject. In the SSC examinations, low-level results were also obtained. Table 2 shows the performance level in the examinations. 
Table 2: Credit Performance in SSC Examinations in Sampled Schools

\begin{tabular}{cccccc}
\hline Years & $\begin{array}{c}\text { English } \\
\text { language } \\
\%\end{array}$ & Mathematics & Physics & Chemistry & Biology \\
\hline 2000 & 8 & $\%$ & $\%$ & $\%$ & $\%$ \\
2001 & 9 & 12 & 9 & 24 & 13 \\
2002 & 13 & 14 & 11 & 26 & 19 \\
2003 & 20 & 16 & 17 & 28 & 25 \\
\hline
\end{tabular}

Source: Statistics Division, Ministry of Education, Akure

As indicated in Table 2, the performance level of students in the five subjects was low and almost the same in all the subjects. A correlational analysis was utilized in testing the hypothesis that there is no significant relationship between students' performance in the overall JSC examinations and the performance in the overall SSC examinations in Ondo State, Nigeria. The findings are shown in Table 3.

Table 3: Performance in the Overall JSC and SSC Examinations

\begin{tabular}{|c|c|c|c|c|c|}
\hline Variable & $\mathrm{N}$ & $\bar{y}$ & $\mathrm{SD}$ & $\mathrm{r}$ cal. & $\mathrm{r}$ table \\
\hline $\begin{array}{c}\text { Overall Performance } \\
\text { at JSCE }\end{array}$ & 206 & 1.47 & .81 & .68 & .1946 \\
\hline $\begin{array}{c}\text { Overall Performance } \\
\text { at SSCE }\end{array}$ & 206 & 1.38 & .84 & \\
\hline \multicolumn{4}{|c|}{$\mathrm{p}<0.05$}
\end{tabular}

As indicated in Table 3, the calculated r (.68) was greater than the table $\mathrm{r}(.1946)$. Hence, the null hypothesis that 'there is no significant relationship between students' performance in JSC English Language examinations and students' performance in SSC English Language examinations in Ondo State, Nigeria' was rejected. This shows that there was a significant relationship between the students' performance in JSC examination and the performance in SSC examinations in the State.

The data for the individual subjects were further subjected to correlational analysis to test the relationship between the performance of students in the various subjects in the JSC and the SSC examinations. The findings are presented in Tables 4, 5, 6, 7 and 8.

Table 4: Performance in JSC English Language and SSC English Language

\begin{tabular}{cccccc}
\hline Variable & $\mathrm{N}$ & $\overline{1}$ & $\mathrm{SD}$ & $\mathrm{R}$ cal. & $\mathrm{r}$ table \\
\hline $\begin{array}{c}\text { Performance in English } \\
\text { Language at JSCE } \\
\begin{array}{c}\text { Performance in English } \\
\text { Language at SSCE }\end{array}\end{array}$ & 206 & .512 & .16 & .62 & .1946 \\
\hline $\mathrm{p}<0.05$ & 206 & .509 & .15 & & \\
\hline
\end{tabular}

Table 5: Performance in JSC Mathematics and SSC Mathematics

\begin{tabular}{cccccc}
\hline Variable & $\mathrm{N}$ & $\overline{1}$ & $\mathrm{SD}$ & $\mathrm{r}$ cal. & $\mathrm{r}$ table \\
\hline $\begin{array}{c}\text { Performance in } \\
\text { Mathematics at JSCE }\end{array}$ & 206 & .51 & .16 & .09 & .1946 \\
$\begin{array}{c}\text { Performance in } \\
\text { Mathematics at SSCE }\end{array}$ & 206 & .38 & .09 & & \\
\hline & $\mathrm{P}>0.05$ & &
\end{tabular}


Table 6: Performance in JSC Integrated Science and SSC Physics

\begin{tabular}{lccccc}
\hline Variable & $\mathrm{N}$ & $\boldsymbol{\gamma}$ & $\mathrm{SD}$ & $\mathrm{r}$ cal. & $\mathrm{r}$ table \\
\hline $\begin{array}{l}\text { Performance in } \\
\text { Integrated Science at }\end{array}$ & 206 &, 57 & .21 & .13 & .1946 \\
$\quad \begin{array}{l}\text { JSCE } \\
\begin{array}{c}\text { Performance in Physics } \\
\text { at SSCE }\end{array}\end{array}$ & 206 & .34 & .15 & & \\
\hline & $\mathrm{P}>0.05$ & & &
\end{tabular}

Table 7: Performance in JSC Integrated Science and SSC Chemistry

\begin{tabular}{cccccc}
\hline Variables & $\mathrm{N}$ & $\mathrm{y}$ & $\mathrm{SD}$ & $\mathrm{r}$ cal. & $\mathrm{r}$ table \\
\hline $\begin{array}{c}\text { Performance in Integrated } \\
\text { Science at JSCE }\end{array}$ & 206 & .57 & .21 & .62 & .1946 \\
$\begin{array}{c}\text { Performance in Chemistry } \\
\text { at SSCE }\end{array}$ & 206 & .53 & .19 & \\
\hline & $\mathrm{p}<0.05$ & &
\end{tabular}

Table 8: Performance in JSC Integrated Sc. and SSC Biology Examinations

\begin{tabular}{lccccc}
\hline \multicolumn{1}{c}{ Variable } & $\mathrm{N}$ & $\bar{\gamma}$ & $\mathrm{SD}$ & $\mathrm{r}$ cal. & $\mathrm{r}$ table \\
\hline $\begin{array}{l}\text { Integrated Science at } \\
\text { JSCE }\end{array}$ & 206 &, 57 & .21 & .65 & .1946 \\
Biology at SSCE & 206 & 54 & .20 & & \\
\hline & $\mathrm{p}<0.05$ & & &
\end{tabular}

In Table 4, the calculated $r$ (.62) was greater than the table $r$ (.1946). Hence, the null hypothesis that 'there is no significant relationship between students' performance in JSC mathematics examinations and students' performance in SSC mathematics examinations in the State' was rejected. This shows a significant relationship between students' performance in JSC English Language examination and students' performance in SSC English Language examinations.

In Table 5, the calculated $r(.09)$ was less than the table $r(.1946)$. Hence, the null hypothesis that 'there is no significant relationship between students' performance in JSC Integrated science examinations and students' performance in SSC Physics examinations in the State' was accepted. This shows no significant relationship between students' performance in JSC Mathematics examination and students' performance in SSC Mathematics examinations.

In Table 6, the calculated $r$ (.13) was less than the table $r(.1946)$. Hence, the null hypothesis that 'there is no significant relationship between students' performance in JSC Integrated science examinations and students' performance in SSC Chemistry examinations in the State' was accepted. This shows no significant relationship between students' performance in JSC Integrated Science examination and students' performance in SSC Physics examinations.

In Table 7, the calculated $r$ (.62) was greater than the table $r$ (.1946). Hence, the null hypothesis that 'there is no significant relationship between students' performance in JSC Integrated science examinations and students' performance in SSC Biology examinations in the State' was rejected. This indicates a significant relationship between students' performance in JSC Integrated Science examination and the performance in SSC Chemistry examinations. 
Table 8 shows that the calculated $r(.65)$ was greater than the table $r(.1946)$. Hence, the null hypothesis that 'the performance of students in the JSC examinations is not a significant predictor of the performance of the same students at the SSC examinations in Ondo State, Nigeria' was rejected. This shows a significant relationship between the students' performance in JSC Integrated Science examination and students' performance in SSC Biology examinations.

Table 9 shows a correlation matrix of the independent and dependent variables for the hypotheses tested showing the correlation coefficients and probability values for each pair of variables.

Table 9: Correlation Matrix of Independent Variables and Dependent Variable

\begin{tabular}{|c|c|c|c|c|c|c|c|c|c|c|}
\hline Variables & 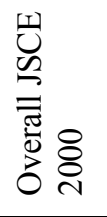 & 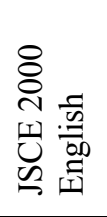 & 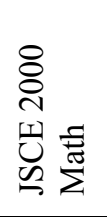 & 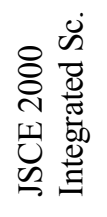 & 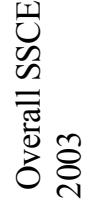 & 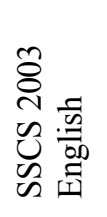 & 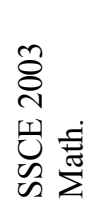 & 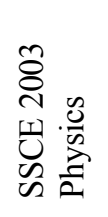 & 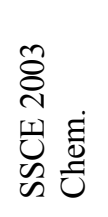 & 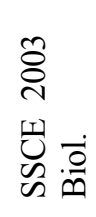 \\
\hline $\begin{array}{l}\text { Overall } \\
\text { JSCE } 2000\end{array}$ & $1 . .00$ & & & & & & & & & \\
\hline $\begin{array}{l}\text { JSCE } 2000 \\
\text { English }\end{array}$ & $\begin{array}{c}.52 \\
p=.00\end{array}$ & 1.00 & & & & & & & & \\
\hline JSCE 2000 & .09 & -.12 & 1.00 & & & & & & & \\
\hline Math & $\mathrm{p}=.12$ & $\mathrm{p}=.06$ & & & & & & & & \\
\hline JSCE 2000 & .46 & .57 & .41 & 1.00 & & & & & & \\
\hline Integrated Sc. & $\mathrm{p}=.00$ & $\mathrm{p}=.00$ & $\mathrm{p}=.00$ & & & & & & & \\
\hline Overall SSCE & .68 & .68 & .18 & .47 & 1.00 & & & & & \\
\hline 2003 & $\mathrm{p}=.00$ & $\mathrm{p}=.00$ & $\mathrm{p}=.02$ & $\mathrm{p}=.00$ & & & & & & \\
\hline SSCE 2003 & .45 & .62 & .31 & .55 & .63 & 1.00 & & & & \\
\hline English & $\mathrm{p}=.00$ & $\mathrm{p}=.00$ & $\mathrm{p}=.00$ & $\mathrm{p}=.00$ & $\mathrm{p}=.00$ & & & & & \\
\hline SSCE 2003 & .12 & .10 & .09 & .08 & -.11 & -.13 & 1.00 & & & \\
\hline Math & $\mathrm{p}=.06$ & $\mathrm{p}=.09$ & $\mathrm{p}=.19$ & $\mathrm{p}=.19$ & $\mathrm{p}=.06$ & $\mathrm{p}=.12$ & & & & \\
\hline SSCE 2003 & .09 & .11 & .07 & .13 & .09 & -.12 & -.17 & 1.00 & & \\
\hline Physics & $\mathrm{p}=.19$ & $\mathrm{p}=.06$ & $\mathrm{p}=.12$ & $\mathrm{p}=.01$ & $\mathrm{p}=.15$ & $\mathrm{p}=.06$ & $\mathrm{p}=.07$ & & & \\
\hline SSCE 2003 & .51 & .47 & .14 & .62 & .56 & -.61 & .43 & .37 & 1.00 & \\
\hline Chemistry & $\mathrm{p}=.00$ & $\mathrm{p}=.00$ & $\mathrm{p}=.06$ & $\mathrm{p}=.00$ & $\mathrm{p}=.00$ & $\mathrm{p}=.00$ & $\mathrm{p}=.00$ & $\mathrm{p}=.00$ & & \\
\hline SSCE 2003 & .42 & .46 & .31 & .65 & .43 & .26 & .28 & .21 & 32 & 1.00 \\
\hline Biology. & $\mathrm{p}=.00$ & $\mathrm{p}=.00$ & $\mathrm{p}=.00$ & $\mathrm{p}=.00$ & $\mathrm{p}=.00$ & $\mathrm{p}=.01$ & $\mathrm{p}=.01$ & $\mathrm{p}=.01$ & $\mathrm{p}=.00$ & \\
\hline
\end{tabular}

Since the larger the value of ' $r$ ', the stronger the association between the two variables (Berenson and Levine 1979), it means that the pairs of variables with large correlation coefficients had strong association with each other.

In order to determine the inter-correlation among variables put together, multiple regression analysis was conducted. The criterion variable was the credit performance in 2003 SSC examinations while the predictor variables included year 2000 JSC examination performance in the English Language, Mathematics and Integrated Science. The findings are shown in Table 10. 
Table 10 Multiple Regression Analysis of Predictor variables with the Criterion Variable Credit Performance in SSC 2003 Examination

\begin{tabular}{|c|c|c|c|c|c|}
\hline Predictor Variables & B & SE B & Beta & $\mathrm{T}$ & Signif. $\mathrm{t}$ \\
\hline $\begin{array}{l}\text { Overall Credit Perf. in } 2000 \\
\text { JSCE }\end{array}$ & .4127 & 6.1736 & .3534 & 1.3649 & .0000 \\
\hline $\begin{array}{l}\text { Credit Perf. in } 2000 \text { JSCE } \\
\text { English Lang. }\end{array}$ & .4534 & .0010 & .3045 & 1.2066 & .0000 \\
\hline $\begin{array}{l}\text { Credit Perf. in } 2000 \text { JSCE } \\
\text { Mathematics }\end{array}$ & .3163 & .1365 & .2421 & -18.36 & .1000 \\
\hline $\begin{array}{l}\text { Credit Perf. in } 2000 \text { JSCE } \\
\text { Integrated Science }\end{array}$ & .4203 & .0167 & .2078 & .2 .745 & .0200 \\
\hline (constant) & 2.5162 & .0316 & & 96.468 & .0000 \\
\hline
\end{tabular}

Thus, the regression equation derivable from the Table 6 is:

$$
\begin{gathered}
Y=2.5162+0.4534 \text { (JSCE English Lang.) }+0.4203 \text { (JSCE Integrated. Sc) } \\
+0.4127 \text { (JSCE Overall Performance) }
\end{gathered}
$$

As indicated in Table 10, all the variables entered the regression equation. The multiple $\mathrm{R}$ was 0.7145 , the R Square was 6142 , the adjusted R Square was 0.6101 while the standard error was 0.0674. Table 11 shows the significant $t$ values derived form the regression analysis.

\begin{tabular}{|c|c|c|c|c|c|c|}
\hline $\begin{array}{l}\text { Predictor } \\
\text { Variables }\end{array}$ & $\begin{array}{c}\text { Credit } \\
\text { Perf. } \\
2003 \\
\text { SSCE } \\
\text { English }\end{array}$ & $\begin{array}{l}\text { Credit } \\
\text { Perf. } \\
2003 \\
\text { SSCE } \\
\text { Math }\end{array}$ & $\begin{array}{c}\text { Credit } \\
\text { Perf. } \\
2003 \\
\text { SSCE } \\
\text { Physics }\end{array}$ & $\begin{array}{c}\text { Credit } \\
\text { Perf. } 2003 \\
\text { SSCE } \\
\text { Chemistry }\end{array}$ & $\begin{array}{c}\text { Credit } \\
\text { Perf. } \\
2003 \\
\text { SSCE } \\
\text { Biology }\end{array}$ & $\begin{array}{c}\text { Credit } \\
\text { Perf. } \\
2003 \\
\text { SSCE } \\
\text { Overall } \\
\text { Perf. }\end{array}$ \\
\hline & Signif. $t$ & Signif. t & Signif. $\mathrm{t}$ & Signif. $t$ & Signif. $t$ & Signif. $\mathrm{t}$ \\
\hline $\begin{array}{l}\text { Overall Credit Perf. in } \\
2000 \text { JSCE }\end{array}$ & .02 & .03 & .04 & .02 & .02 & .03 \\
\hline $\begin{array}{l}\text { Credit Perf. in } 2000 \text { JSCE } \\
\text { English Lang. }\end{array}$ & .01 & .03 & .50 & .03 & .01 & .00 \\
\hline $\begin{array}{l}\text { Credit Perf. in } 2000 \text { JSCE } \\
\text { Math }\end{array}$ & .02 & .12 & .08 & .09 & .06 & .10 \\
\hline $\begin{array}{l}\text { Credit Perf. in } 2000 \text { JSCE } \\
\text { Integrated Sc. }\end{array}$ & .05 & .03 & .10 & .03 & .01 & .00 \\
\hline (constant) & .01 & .12 & .10 & .01 & .00 & .00 \\
\hline
\end{tabular}

Table 11: Output of the Multiple Regression Analysis

As indicated in Table 11, the variables that entered the regression equation at 0.05 level of significance included JSC 2000 English Language, JSC 2000 Integrated Science and the overall JSCE 2000 performance. The best predictor of performance was the JSC 2000 English Language. It contributed $45 \%$ to the criterion variable. Other predictors included the JSCE 2000 Integrated Science which contributed $42 \%$ to the criterion variable and the overall Performance in the 2000 JSCE examination which contributed $41 \%$. The relative effects of the independent variables (JSCE 2000) on the dependent variable (SSCE 2003) are indicated in Table 12. 
Table 12: Effects of the Independent Variables (JSCE 2000) on the Dependent Variable (SSCE 2003)

\begin{tabular}{|c|c|c|c|c|c|c|c|c|c|}
\hline \multirow[b]{2}{*}{ Subjects } & \multicolumn{2}{|c|}{ Sum of Squares } & \multicolumn{2}{|c|}{ Mean Squares } & \multirow{2}{*}{$\frac{0}{\sum_{2}^{2}} \simeq$} & \multirow{2}{*}{$\mathscr{2}$} & \multirow{2}{*}{ 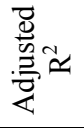 } & \multirow{2}{*}{ L } & \multirow{2}{*}{+} \\
\hline & Regression & Residual & Regression & Residual & & & & & \\
\hline $\begin{array}{l}\text { English } \\
\text { Lang. }\end{array}$ & .56 & 3.72 & .13 & .02 & .41 & .25 & .23 & 12.1 & .00 \\
\hline Math & .57 & 7.1 & .12 & .02 & .37 & .24 & .18 & 3.4 & .10 \\
\hline Physics & 1.37 & 3.95 & .34 & .03 & .38 & .29 & .21 & 18.3 & .06 \\
\hline Chemistry & 2.31 & 7.41 & .48 & .03 & .43 & .27 & .25 & 20.5 & .01 \\
\hline Biology & 1.12 & 5.97 & .24 & .03 & .47 & .25 & .23 & 11.3 & .00 \\
\hline $\begin{array}{l}\text { Overall } \\
\text { Perf. }\end{array}$ & 22.8 & 87.2 & 5.1 & .37 & .45 & .28 & .24 & 12.5 & .00 \\
\hline
\end{tabular}

In Table 12, the probability was less than 0.05 in the overall performance of students and in English Language, Chemistry and Biology. This shows that there was a significant relationship between all the predictor variables and the credit performance of students in these subjects in the 2003 SSC examinations. The regression equation has also predicted a significant amount of the adjusted $\mathrm{R}^{2}$. In the overall performance, the variables predicted $24 \%$ of the variance, that is, the value of adjusted $\mathrm{R}^{2}$. The variables also predicted $23 \%$ of the variance in English Language, $18 \%$ of the variance in Mathematics, $21 \%$ of the variance in Physics, $25 \%$ of the variance in Chemistry and $23 \%$ of the variance in Biology. This shows that the JSC performance was a fairly low predictor of academic performance in the SSC examinations.

\section{Discussion}

In the foregoing, the predictive strength of the JSC examinations in predicting performance at the SSC examinations in Ondo State, Nigeria was examined. Although the performance level was low in the examinations thereby supporting earlier findings (Adeyegbe, 2002; Oderinde, 2003; Onipede, 2003), the performance varied considerably form one subject to another. The findings tend to agree with those of some previous researchers (Durotoluwa 2000). In some cases, the findings tend to disagree with those of some other researchers (Omonijo, 2001; Asaolu, 2003, Oluwatayo, 2003). The findings indicating significant relationship between the performance of students in the JSC 2000 and the performance of the same students in the SSC 2003 examinations agreed with those of Othuon \& Kishor (1994) who found that the Kenya certificate of primary education (CPE) had a moderate linear relationship with the Cambridge secondary certificate (CSE) examination grades. The findings were in consonance with the findings made by Ubokobong (1993) that students with high number of credits in Nigerian secondary school examinations performed well in higher institutions. The findings also agreed with Ojerinde's (1974) findings on the prediction of academic success in the school certificate examination from the National Common Entrance examination scores.

The findings were, however, contrary to the findings made by Adebayo (2002) who found no significant relationship between students' overall performance in the JSC and the SSC examinations in Ekiti State, Nigeria. The findings were at variance with the findings made by Afolabi and Adewolu (1998) who reported that the Osun State JSC examination is a poor predictor of students in the SSC examinations. This suggests that further research should still be conducted in this area. The findings on indicating that performance in JSC Integrated Science could effectively predict performance in SSC Chemistry and Biology were however, contrary to the findings made by Omonijo (2001) who reported that the JSC Integrated Science could not singly predict the performance of students at the SSC Chemistry and Biology. The findings indicating that the JSC Mathematics was not a good predictor of performance in SSC Physics negated the findings made by Asaolu (2003) who claimed that JSC Mathematics examination 
was a good predictor of performance at the SSC Physics in secondary schools in Ekiti State, Nigeria. The findings indicating that the JSC Mathematics was not a good predictor of performance in SSC Mathematics also negated the findings made by Adelugba (2003) who reported that the JSC Mathematics was the best predictor of SSC Mathematics examinations. The findings however agreed with the findings made by Adelugba (2003) that the JSS English Language is the best predictor of performance in the SSC English Language. It was however, noticed that multiple regression revealed more about the variables and their relationship with students' credit performance in the SSC examinations This might be due to the fact that multiple regression provides an estimate of the variance in the criterion variable accounted for by the predictor variables.

\section{Conclusion}

Based of the findings of this study, it is concluded that the performance of students at Junior Secondary Certificate (JSC) examinations is a moderate predictor of academic performance of students at the senior secondary certificate (SSC) examinations in Ondo state, Nigeria. Considering the findings, it is recommended that the JSC curriculum should be reviewed in line with the SSC syllabi in the various subjects and in accordance with the provisions of the National Policy on Education (1998). Government should organize more induction courses, seminars and workshops for teachers to expose them to new strategies in teaching while the State Ministry of Education should embark upon more inspection and monitoring of schools to ensure that effective teaching and learning take place in schools.

\section{References}

Adebayo, A (2002). "Predictive validity of the junior secondary school certificate examinations (JSCE) for academic performance in senior secondary school certificate examinations (SSCE) in Ekiti State, Nigeria." Unpublished M.Ed Thesis, University of Ado-Ekiti, Nigeria, 60-62.

Adelugba, O.O (2003). "Students' performance in junior secondary school certificate examinations as predictor of performance in senior school certificate examinations in Ekiti State, Nigeria." Unpublished M.Ed Thesis, University of Ado-Ekiti; Nigeria, 68-70.

Adesina, S (1977) Planning and educational development in Nigeria Lagos: The Academic Press, 24-129.

Adeyegbe, S. O. (2002). "How students examiners perform at WAEC Examinations" Education and Manpower, Vanguard; December 19, 22.

Adeyemi, T.O (1998) "School and teachers variables associated with the performance of students in the senior secondary certificate examinations in Ondo-State, Nigeria." Unpublished PhD Thesis, University of Hull, UK, 203-208.

Adeyemo, G. A (2001). "Teacher and student variables as correlates of achievement in Integrated Science in Ibadan North Local Government Area of Oyo State" Unpublished M.Ed Thesis, Faculty of Education, University of Ado-Ekiti; Nigeria, 40-45

Afolabi, E. R \& Adewolu, B. A (1998). "The predictive validity of Osun State junior secondary school examination, Nigerian Journal of Social and Educational Research 1 (1); 35-42

Alonge, M.F (1998) Implications of probabilistic models of item analysis to educational evaluation, Journal of Educational Research, (2) 50-56.

Al-Shorayye, S. R (1995). "The effect of admissions policy, socio-economic factors, and demographic and personal considerations on students' performance at Kuwait University." Unpublished PhD Thesis, University of Hull UK, 142-145. 
Asaolu, A. G (2003). Predictive validity of JSC mathematics examination on the performance of students in science subjects in Ekiti State secondary schools" Unpublished M.Ed Thesis, Faculty of Education, University of Ado-Ekiti; Nigeria, 50-76.

Bello, G (2000). "Scientific development and the challenge of science education" Nigerian Journal of Educational Research and Evaluation A Publication of the National Association of Educational Researchers and Evaluators. 2 (2), 10-11.

Berenson, Mark L \& Levine, David M (1979). Basic business statistics: Concepts and applications London: Prentice/Hall International Inc, 325- 387, 401- 464, 492- 515.

Daniels, M \& Schouten, J (1970). "Education in Europe: the screening of students, problems of assessment and prediction of academic performance" Council for Cultural Cooperation of the Council of Europe. London: George Harrap Co. Ltd, 65.

Durotoluwa, J. O (2000). "Predictive validity of JSS certificate examinations in mathematics: A case study of Owo Local Government Area". Educational Thought, Journal of Faculty of Education, Ondo State University, Akungba-Akoko 1 (1) 30-34.

Federal Republic of Nigeria (1998). National policy on education 3rd Edition, NERDC Yaba, Lagos 7, 44-45.

Gay, L. R (1996). Educational research: competencies for analysis and application; Upper Saddle River, New Jersey: Merrill, Prentice-Hall Inc, 249-305.

JAMB (2002). JAMB Brochure, Abuja: Joint Admissions and Matriculation Examinations, 2-3.

O'Rourke, B. Martin, M. O, \& Hurley, J. F (1989) “The scholastic aptitude Test as a Predictor of third-level academic performance" The Irish Journal of Education XXIII, (1), 22 -35 .

Oderinde, B. B. (2003). "Examinations and students performance" Vanguard 19 (5167), Thursday, January $16 ; 30$.

Ojerinde, A (1974). "Prediction of academic success in school certificate examination from the National Common Entrance examination scores" Unpublished M.Ed Dissertation, Faculty of Education, University of Ife, Ile-Ife, Nigeria.

Oluwatayo, J. A (2003). "Mode of entry and performance of Nigerian universities undergraduates in science courses." Unpublished $\mathrm{PhD}$ Thesis, University of AdoEkiti, Nigeria, 63, 147-165.

Omonijo, A. R (2001). "Junior secondary certificate results in integrated science as a predictor of performance in science and mathematics in the senior secondary certificate examinations". Unpublished M.Ed Thesis, University of Ado-Ekiti, Nigeria 79- 82.

Ondo State, Ministry of Education (2001). "Educational statistics" Akure: Planning and Statistics Department, Ministry of Education; 1-3.

Onipede, H (2003). "National development hinges on quality education" The Comet, Thursday, January 2; 21.

Othuon, L \& Kishor, N (1994) "Hierarchical linear modelling of predictive validity: The case of Kenya certificate of primary education examination" Studies in Educational Evaluation 20, 181-190.

Owoyemi, N (2000). "Moderation and standardisation of continuous and terminal assessment scores in junior secondary school certificate examination and primary school leaving certificate assessment' Paper delivered at the senior staff seminar, Ministry of Education, Ado-Ekiti $2^{\text {nd }}$ March, 2-9. 
Peers, Ian S \& Johnston, Margaret (1994). "Influence of learning context on the relationship between A- Level attainment and final degree performance: A meta-analytic review" British Journal of Educational Psychology 64, 1-15.

Salami, A (1992). "Raising the standard of performance in public examination" Paper presented at the WAEC Symposium held at the University of Ibadan, Nigeria 24th April, 1-3.

Ubokobong, H.E (1993). "Predicting educational performance at tertiary level on the basis of secondary level performance" International Journal of Mathematical Education in Science and Technology 24 (2), 287.

West African Examinations Council (2002). "Standards in subjects: West African School Certificate" Lagos: West African Examinations Council Yaba, Nigeria. December; 210. 